\title{
The Discourse of Global Compassion and the Media
}

\author{
Birgitta HöIJER
}

The sentiment of compassion is increasingly exploited in politics and in the media. We may talk about a compassionate trend or, more broadly, a developing discourse of compassion.

The purpose of this article is to discuss that development with a special focus on global compassion and the role of the media. The media expose pictures of distant victims of civil wars, genocide, massacres and other violence against civil populations, and play a basic role in giving publicity to human suffering. The audience is expected to respond as good citizens with compassion and rational commitment.

But the discourse of global compassion is wider than that. It is embedded in different institutional contexts. A global discourse of compassion has extended and developed in the intersection between politics, humanitarian organisations, the media and the audience/citizens. Today it frames our thinking our political, journalistic and everyday thinking about violence and conflicts in the world. In Western politics there is a growing focus on human suffering in relation to distant crises and wars, so also in the media and among citizens in general. Global compassion is considered to be morally correct in the striving for cosmopolitan democracy, and the international community condemns "crimes against humanity". The role of humanitarian aid agencies is becoming increasingly important in global crises and people in the West are getting more involved in NGO:s. The article will also bring up these institutional contexts.

Before going into the discourse of global compassion the concepts of "discourse" and "compassion" will be treated respectively.

Media and Communication, Department of Humanities, Örebro University, birgitta.hoijer@hum.oru.se

\section{The Concept of Discourse}

The concept of "discourse" certainly is fuzzy and has been given many different meanings. Most academics, however, seem to agree that discourses have to do with ways of speaking about and understanding the world (Jørgensen \& Phillips, 1999). But discourse points at more than mere texts, and speaking should not be understood as only verbal utterances. According to Fairclough (1989: 25) discourse "involves social conditions, which can be specified as social conditions of production, and social conditions of interpretation. These social conditions, moreover, relate to three different 'levels' of social organization: the level of the social situation, or the immediate social environment in which the discourse occurs; the level of the social institution which constitutes a wider matrix for the discourse; and the level of the society as a whole." Discourse here is a very wide concept covering social phenomena at macro and micro levels and putting them in relation to each other. Fairclough talks about social structures as the most abstract level, social practices as the middle level, and social events as the most concrete level, where we, for instance, find specific texts. ${ }^{1}$ Discourse, then, is a very inclusive umbrella concept, which may be used in relation to most social phenomena.

Recently, Fairclough defined discourse as "positioned ways of representing" and emphasised the importance of differentiating between discourse, genre, and style. ${ }^{2}$ His definitions were not very clear however. ${ }^{3}$

The confusion about the concept and the widely varied use of $i^{4}$ - here only Fairclough's definitions have been mentioned but his view is only one among several others - seem to make any attempt at fixing a meaning fruitless. Instead we may, in ac- 
cordance with the general emphasis on "context" in most discourse theories, have the social and scientific context of the specific research in mind when specifying its meaning. In the following, then, discourse is seen as a prominent socio-cognitive perspective at macro and micro levels of a social phenomenon, which is socio-politically determined and expressed in communication and in action.

The discourse of global compassion, which will be discussed here, permeates Western thinking, arguing, and acting in relation to distant violence and conflicts at macro and micro levels.

\section{The Concept of Compassion}

According to Nussbaum (2001: 301) compassion is "a painful emotion occasioned by the awareness of another person's undeserved misfortune". She regards compassion as a complex emotion including such cognitive beliefs that the suffering of the other is serious, and that the suffering person does not deserve the pain (Nussbaum, 2001: $306 \mathrm{ff}$.). This makes the suffering person an innocent victim of some gruesome acts or circumstances. Following Nussbaum we may conclude that compassion is both an affective and a cognitive reaction.

In line with Tester (2001: 18) the concept of compassion will here be reserved for compassion with the suffering of others in the public sphere. Other concepts, such as, empathy, sympathy, or even altruism, may also be relevant, but they do not include the same public and political dimensions as the concept of compassion. Boltanski (1999: 6) uses, inspired by Hanna Arendt, the concept of "pity" instead of compassion. For him compassion is without generalisations, it is purely local and specific and it is linked to the face-to-face presence of particular individuals. Pity, on the other hand, "generalises and integrates the dimension of distance", and is more political. A politics of pity is, according to Boltanski (1999: 12) "not just concerned with one unfortunate and a particular situation. To be a politics it must convey at the same time a plurality of situations of misfortune, to constitute a kind of procession or imaginary demonstration of unfortunates brought together on the basis of both their singularity and what they have in common". This is exactly what is meant by "compassion" for other writers and also in this article.

According to Sznaider (1998) public compassion originates in an abstract, theoretical and rational idea of humanity, not in religious charity. It is closely connected with the ideas of the Enlightenment and the humanitarian movements that arose in the eighteenth and the nineteenth centuries, such as movements to abolish slavery, child labour, and so on. Sznaider defines two perspectives on public compassion: one related to democratisation processes in which equality is central, and the other related to the market society, in which an extending exchange of goods and services unintentionally also extends the moral concern for strangers. He also discusses the Marxist critique according to which compassion is "nothing other than the narcissistic desires of an exploitative bourgeoisie to feel good about itself" (Sznaider, 1998: 121). We certainly may or may not agree with Sznaider in his view on capitalism and Marxism, but his notion about the connection between public compassion and democratisation processes is more reasonable. Human rights and democratisation is increasingly being acknowledged to firmly belong together (Beetham, 1998).

In the following, compassion has to do with perceiving the suffering and the needs of distant others through media images and reports. Global compassion is then a moral sensibility or concern for remote strangers from different continents, cultures and societies. The discourse of global compassion takes place in the intersection between politics, humanitarian organisations, the media, and the audience/citizens.

\section{Global Compassion and International Politics}

If we start with the macro-political perspective, there is an increased political willingness to pay attention to internal national conflicts and civil wars with victims among the civilian population - at least some conflicts and civil wars - and view them as threats to global security (Minear, Scott \& Weiss, 1996). During the Cold War period the international action by the power nations was guided by the global ideological struggle between capitalism and communism. People in the West were stamped in their political thinking and engagement by these ideologies. Today, other thought models form our understanding and engagement, or lack of engagement, in distant conflicts. Two current thought models or perspectives are discussed by Ignatieff (1998), on the one hand the new nationalism with ethnic claims and conflicts, and on the other hand a moral universalism that is based on human rights.

The so called New World Order - a term launched by the former president George Bush in connection with the Gulf War - proclaims that a combination of market economy and human rights 
will lead to a more just and democratic world. ${ }^{5}$ The social-democratic leaders of today's Europe share this view. According to Johnstone (2000: 14-15) capitalism is no problem for what she calls the "third way" of the left. Economic forces are regarded as "innocent, even benevolent". The enemy is instead nationalism, which, we may add, since September 11th 2001 includes fundamentalist terrorism, and which is regarded as the "cause of war, oppression and violation of human rights".

Accordingly, after the end of the Cold War politicians in the West no longer motivate international intervention in the rhetoric of political ideologies or power interests but in the rhetoric of human rights and global compassion. In public, territorial and economic claims are not mentioned, although they certainly may exist in the hidden agenda and be basic motives for intervention. Instead, it is crimes against humanity that must be stopped, it is publicly said (for criticism of this enterprise see Chomsky, 1999). The enemy will be defeated for its present or future violence against civilian populations: Slobodan Milosevic for ethnic cleansing and the massacres of Kosovo-Albanians, Osama bin Laden for the civilians killed in the terror attack against the World Trade Centre, Saddam Hussein for potential future civilian victims of mass destruction weapons. These encroachments are terrible and detestable. However, international interventions inevitably give rise to new victims among civilian populations. Euphemisms, such as "humanitarian interventions" are used to bridge the contradictions. This was done when NATO and the U.S. dropped bombs over Kosovo and Serbia in the spring 1999. And when the U.S. and Britain started their bombing campaign in Afghanistan in order to defeat the Talebans and Osama bin Laden they simultaneously dropped humanitarian aid in the form of food bombs. In order to been seen as the Good Samaritan, U.S. aircrafts dropped 37,500 yellow food packages over Afghanistan (Reuters News, 9 Oct 2001). A military victory would not be enough: "The U.S. must also win a global war for hearts and minds. If the first wave of allied aircraft over Afghanistan carried food, not bombs, Mr Bush might claim a resounding moral victory". ${ }^{6}$

We should, of course, ask if political global compassion as a matter of fact is an ideology of social control with a hidden agenda of power, more than being part of an unselfish moral ideology of human rights. This is, however, not the topic for this paper.

Through extensive media coverage images of distant suffering have also become part of ordinary citizens' perceptions of conflicts and crises in the world. Further, humanitarian non-governmental organisations have been growing in number and membership and they have attained more prominent positions in the West (Tvedt, 1993). In business life we find spokesmen for "corporate compassion" as a way to long-lasting success (Lynch, 1998) ${ }^{7}$, and one trend within marketing is humanitarian sponsoring in which big companies give money and other resources to social and humanitarian aid. Companies want to attain goodwill by being seen as benefactors and human sponsoring is a fast growing form of sponsoring today. ${ }^{8}$ Of course, it may be discussed if this is a cynical exploitation of human suffering, or an expression of true compassion. Here, however, it is enough to draw attention to the phenomenon as part of a humanitarian trend in the West, the defence of human rights, which is to be seen as one aspect of the globalisation process (cf. Beck, 2000; Sassen, 1998) and which is important in the new way of thinking about democracy (Beetham, 1998). In International Courts of Justice and Human Rights, war crimes such as massacres of civilians and genocide are brought up and the aim is to punish responsible politicians, members of armed forces, and individual perpetrators. After a few temporary war crime tribunals set up for specific human rights violations, for example those in former Yugoslavia and Rwanda, a permanent International Criminal Court (ICC) is now being set up on the initiative of the United Nations General Assembly. In July 2002, 82 countries had ratified the statute of the court. The Government of the U.S. has, however, informed the United Nations Secretary-General Kofi-Annan that "the United States does not intend to become a party to the treaty". 9

\section{Global Compassion and News Media}

It is hard to find the chicken and the egg in the development of global compassion because there is a complex interplay of factors behind it rather than a linear causal chain of relationships. Anyway, media coverage seems to be something of a driving force in the development influencing both the public and the politicians. The media may be seen as an intermediate link between the level of social situations, in which audiences' interpretations and responses develop, humanitarian organisations and politics.

The so-called CNN effect refers to the impact of rolling television news about children and other innocent victims of disasters and conflicts on policy makers' awareness of populations in need. One example of the political effect of televised newscasts 
is the pictures of the little girl Irma in a hospital bed in Sarajevo in August 1993. She had lost her mother in one of the many shell fires against the city during the war in Bosnia and she was herself severely injured by shell splinter. The news reports about Irma affected the British Prime Minister John Major and the former Prime Minister Margaret Thatcher to compete over demands for an air bridge which could fly out injured people from the occupied Sarajevo. So was done and also other European countries welcomed injured victims from the war. Another example, noted by Carlgren (1996), is the sanctions that the UN proclaimed against Serbia in 1992 after the shellfire against people queuing for bread in Sarajevo. Television all over the world broadcasted shocking pictures from the senseless attack.

The relationship between media coverage and political reactions and measures is by no means given, however. As Natsios (1996) shows, in his discussion on the United States and humanitarian issues, many factors, such as domestic politics, geopolitical interests, and other coincidental foreign policy crises, influence the process. And the media reporting often becomes part of propaganda strategies. In relation to the Kosovo War, media were occupied by the fate of the Kosovo-Albanian civilian population and their sufferings, partly because it fitted into the NATO propaganda (Höijer, Nohrstedt \& Ottosen, 2002). In the recent Afghanistan War American authorities put pressure on the media to refrain from reporting about civilian casualties and sufferings in order not to adversely affect the public support for the bombings. The chairman of CNN instructed the staff that if such news were going to be broadcast they should balance the reporting of victims in Afghanistan with reminders to the audience of the victims of the terror attack on World Trade Centre and the Pentagon (Ottosen, 2002). As indicated by a study of New York Times also the press seemed to have followed the recommendations (Björnemyr \& Wahlqvist, 2002).

How ever strong or weak, politically ruled or not, the so-called $\mathrm{CNN}$ effect may be in relation to different humanitarian crises, it seems quite obvious that it primarily is through the media that we, citizens and politicians alike, meet depictions of the suffering of distant strangers.

Especially television with its reach and visual impact may therefore play a key role in the fostering of a collective global compassion. Photographic pictures are often perceived as truthful depictions of reality. As audience we experience that we see the innocent victims of the violence with our own eyes, and the pictures become evidence of the suf- fering. The pictures, especially moving pictures, insist upon being paid attention to, and upsetting pictures may also intrude on our memories (Kjellqvist, 1996). Through the media, and especially through the moving images of television, people have become aware of the sufferings of remote others and are challenged to include strangers in their moral conscience. No one can deny the existence of large-scale humanitarian disasters.

The severe drought in Africa in the middle of the 1980 s is often regarded as a kind of break-through for the global humanitarian engagement (Tvedt, 1993). We may, however, go further back in history to the civil war in Nigeria 1968-1970, in which the media coverage focused on the consequences for the civilian population (see Nohrstedt, 1986). Television reported the brutal violence by broadcasting pictures of death and suffering and the humanitarian organisations successfully organised subscription campaigns. Pictures of starving children with swollen stomachs, match-thin arms and legs, and big heads with endless sad-looking eyes were engraved into the collective memory of people. "Biafra child" became a concept and a symbol for the predicament of children as innocent victims. Also some of the well-known pictures from the Vietnam War showed civilian victims, such as the women and children from the massacre of Song My in 1968, and the naked running girl from the napalm bombing of Trang Bang in 1972. Then, however, such pictures were quite unique and became what Andén-Papadopoulos (2000) calls "icons of the Vietnam War". ${ }^{10}$

On the whole, news media are focusing more on civilian populations as victims of conflicts and wars than before. We may talk about a victimisation of civilians in conflict and war journalism. According to the BBC war reporter Martin Bell (1998: 15-16), who has been reporting from wars ever since the mid 1960s, the reporting "has changed fundamentally" from reporting that mainly concerned military aspects, such as strategies and weapon systems, to reporting with a greater focus on people "the people who provoke them, the people who fight them and the people who suffer from them". He believes in what he calls the journalism of attachment: "a journalism that cares as well as knows; that is aware of its responsibilities; that will not stand neutrally between good and evil, right and wrong, the victim and the oppressor" (Bell, 1998: 169). And quantitative content analysis studies show an increased exposure of pictures of human suffering among civilian populations in television news, and that the visual presentations have become more lurid (Cronström, 2000; Höijer, 1994; 
1996). The camera explores faces twisted in pain, or lingers on wounds and bloody bandages, it zooms in on broken and mutilated limbs, or pools of blood, and the injured are not soldiers but ordinary people.

Photographers and journalists may, as Martin Bell, be seriously committed to humanitarian reporting. Mellum (2000) who interviewed Norwegian journalists reporting from the refugee camps during the Kosovo War found that half of them were deeply touched and that this had an effect on their reporting. Some got involved and helped the refugees with different things. One female journalist collapsed when returning home. Several newspapers offered the returning photographers and journalists psychological help in the form of talks with a doctor or psychologist. But media reporting on distant suffering may also be part of more cynical commercial interests, in which the media sell human tragedies in a global market place. In the pursuit of attention, news producers follow the logic of increasingly dramatic coverage, and journalists become desensitised and blasé (Moeller, 1999).

\section{Global Compassion and Entertainment Media}

Television not only pays attention to victims in newscasts but also in entertainment programmes. In the English language, "telethon" is a special word for such programmes. According to Tester (2000: 139) a telethons is:

\section{... a television and/or radio appeal on behalf of a charity or a range of charities. Telethons involve lengthy broadcasts (often of 24 hours) and are invariably aimed at raising funds for specific concerns, e.g. child poverty, famine, flood relief and so forth. Telethon broadcasts are invariably fronted with celebrities and involve the audience engaging in allegedly 'fun' pursuits. Telethons are usually justified on the grounds that, 'it is all about a good cause'.}

A common form of telethon is a broadcast gala show in which artists perform for charitable purposes and the audience is urged to donate money. The programmes often include lotteries in which people who give money can win expensive prizes. In Sweden, a number of humanitarian organisations support the yearly subscription campaign "Världens barn" (the children of the world) ${ }^{11}$ and Swedish Television broadcasts performances directly related to the campaign. In November 2002 the campaign result of the year counted over 100 million
Swedish kronor, and the public service broadcasting company was shouting for joy over the fact that more than two million telephone calls from the audience were made during one particular weekend, a result much higher than the year before. ${ }^{12}$ In Norway, public service television NRK also organises a yearly subscription campaign in co-operation with different humanitarian organisations, such as Amnesty International, SOS Children's Villages or the Salvation Army, and peoples' willingness to donate money is great. Recently 157 million Norwegian kroner were donated, which is very high considering that the population is only approximately 4.5 million. ${ }^{13}$ The royal family, politicians and all the media support the subscriptions and the nation pay tribute to the humanitarian organisations (Tvedt, 1995). Also commercial channels want to be associated with humanitarian goodness. When channel 2 in Norway broadcast the hour-long programme "A hand to hold", more than ten thousand new sponsors for orphans were registered during the programme. ${ }^{14}$ In Great Britain charity programmes (telethons) - for example Live Aid, Children in Need, and Comic Relief - are successful and they appeal to both high and low investors (Tester, 2001).

Telethons are usually nation-based programmes with a global purpose since aid to foreigners of distant suffering often is the goal for the fund-raising. However, by inviting the audience to collectively share individual goodness, national identity may in fact be strengthened. A successful telethon, supported by the royal family (if there is one) and politicians, and in which celebrities, big companies and ordinary people all donate money, may unite the nation in a joint sense of living in security and of being good-hearted.

Very occasionally, a television gala show may be globally broadcasted. One example is when the four big television companies (ABC, CBS, NBC, and Fox) in the United States a couple of weeks after the terror attack of September 11th 2001 together broadcasted a gala show in support for the victims. Many world famous celebrities appeared and donated money and the programme was simultaneously shown on most American television channels and in 156 other countries. ${ }^{15} \mathrm{~A}$ well-known historic media event of a similar kind was the Live Aid in 1985 when a television rock concert for starving people in the world were globally broadcasted. Millions of viewers saw it and millions of pounds were collected (Devereux, 1996).

In recent years we have also seen other forms of charity in entertainment television programmes. For 
example, when a series of song contest programmes for the Swedish Melody Grand Prix were broadcasted, a contribution was made to the subscription campaign "Världens barn" for each phone call placed by the audience to vote for the different songs.

That compassion may be a selling concept for media production in general was recently seen, also in Sweden, when the production company Strix Television AB launched a charity series called "Solidarity". In the information material from Strix the series is categorised as a reality fundraiser, which is presented as "a completely different form of fundraising event". The lives and work in an area of need of volunteer workers linked to an international aid organisation are broadcasted and the audience will be presented with "engaging stories of the aid workers struggle and hardships". The viewers can donate money in a traditional way but are also encouraged to organise "local activities and events to raise money and awareness". ${ }^{16}$

There are many ethical questions which we need to discuss in relation to broadcast entertainment in the cause of distant suffering. Is it not morally dubious to enjoy oneself when people who are addressed as the suffering ones are homeless, starving, injured or in danger? Are the artists who perform in the programmes really performing for the good of the cause or for getting media attention and publicity as artists? What is the moral in arranging lotteries in which one may win luxury cars by giving money for aid? What is the moral in giving publicity to brands for aid?

Campaigns and televised gala shows may be most directly related to activity in the form of economic support for aid, but it is still the informative programmes that create the necessary conditions via their depictions of distant suffering. The news media often hold up different views in issues, but when it comes to compassion with the victims, hegemonic unity prevails.

\section{Global Compassion and Humanitarian Organisations}

According to Ignatieff (1998) the shame of the Holocaust is the breeding ground for the development of a moral universalism, which focuses on innocent victims of political violence. The roles of the UN and UNESCO should, of course, not be underestimated, but there are also many thousands of non-governmental humanitarian organisations helping suffering people in the world. Boltanski (1999) goes further back in history in his understanding of what he names "the politics of pity". However, in the same way as Ignatieff, he claims that the last twenty years of development of non-governmental humanitarian organisations "is something new" (Boltanski, 1999: xiii). Citizens' engagement in the traditional political institutions are decreasing in the West (Karvonen, 1999), but studies show that people are getting more involved in non-governmental organisations (Thörn, 1999). In Norway, almost twice as many citizens are members of humanitarian organisations as of political parties (Andresen, 1999), and a Swedish study concludes that humanitarian organisations are one of the types of organisations that, relatively speaking, increase the most (Jeppsson Grassman \& Svedberg, 1999). Johnstone (2000:15) also notes the growth in humanitarian engagement in the West: "As political parties have declined, the creative centre of the old liberal left has shifted to single-issue and humanitarian non-governmental organisations". The apolitical character of such organisations may even be a reason for their attraction. They are in their philanthropic and altruistic messages and practices raised above the power game and hypocrisy of ordinary politics. They are in the service of humanity, they always side with the victims, and they appeal to our most noble feelings - compassion and altruism.

Minear, Scott and Weiss (1994) have studied the intricate relationships between the media, governments, and humanitarian organisations. "Fund-raising and publicity are the lifeblood of aid agencies," they write, "whether they are seeking governmental or individual support. As a result, jockeying for the attention of the media and donors is routine" ( $p$. 29). They conclude that good contacts in the media world are essential for humanitarian organisations who intend to expose human rights abuses, and they recommend such organisations to "spend considerable resources developing productive working relationships with journalists" (p. 86). The Swedish Red Cross emphasises the power of the media to make people aware of the needs in the world and notes that dramatic pictures in the media serve as a catalyst. According to this organisation there is a clear relationship between subscriptional results and media exposure. ${ }^{17}$

It is not the purpose of this paper to go further into the intricate relationship between humanitarian organisations, the media, and international politics. Instead a fourth party, and a party that all three institutions are dependent on in their social practices will be brought up, namely the public.

The humanitarian organisations are dependent on the public as citizens giving money gifts, the 
media are dependent on the public as audiences paying attention to their texts and programmes, and policy makers are dependent on the public as opinion. Given the mediating role of the media, on the one hand between humanitarian organisations and the public and on the other hand between politics and the public opinion, it makes it especially important to focus on the public as audiences to the humanitarian reporting in the media. How do people react to the emotional engagement media offer by focusing on innocent victims for political conflicts, war, and other violence?

\section{Global Compassion and the Audience}

In the critical media debate it is a quite common view that suffering is commodified by the media and the audience become passive spectators of distant death and pain without any moral commitment. Zizek (2001) emphasises the narcissistic traits of what he calls the capitalistic subjectivity in which we are superficially touched and give money for charity just in order to keep the distant other at an arm's length. Moeller (1999) almost takes for granted that the American audience she discusses do not care about the human suffering they are fed with by the media. Tester, who has addressed many important questions about the media and their significance for the moral values among people and in society, also has a mainly pessimistic view on the audience. He comes to conclusions such as "it is quite likely that the media do not serve so as to sensitise us to moral problems. Quite the contrary; the media rather tend to have an anaesthetic effect. [...] It is perhaps not unreasonable to suggest that the media mean the destruction of the moral values of solidarity" (Tester, 1994: 107). In a later book Tester (2001) refers to studies showing plurality in audience's reactions. This complicates his view on the audience but he withholds a discussion of a theoretically constructed audience who "does not contain the ethical awareness that would make statements of the ought binding or the practice of virtue possible" (Tester, 2001: 50). His book focuses on the compassion fatigue thesis and initially he declares that he is not seeking an answer to the question whether compassion fatigue really exists or not among the audience (p. 2).

The value of discussing a theoretically constructed audience is, however, limited. We need to address real audiences. We need to ask and study how people as audience react to and interpret the media reporting on documentary violence and human suffering. There are a few such studies (Höijer,
1994; Höijer \& Olausson, 2002). The conclusion from this empirical research opposes, or strongly modulates, the thesis about a pronounced compassion fatigue among people in general.

Instead we see a two-sided effect of global compassion on the one hand and ignorance and compassion fatigue on the other. And there are different forms of compassion as well as different forms of indifference (Olausson, 2002; Höijer, in press).

Pictures in the media of suffering people may really invite to a moral compassion at a distance. They may mobilise compassion. Crimes against humanity such as encroachment and violence against people and populations have a strong appeal on the audience, especially on the female audience. It was, for instance, the discourse of global compassion that dominated the spontaneous memories of the Kosovo War, most strongly among the women (Höijer \& Olausson, 2002). The mass desertions and the human suffering were in focus and the audience remembered the television pictures of streams of refugees or pictures of crying people in refugee camps.

The other reaction to the media focus on distant human suffering, i.e. turning away and not letting oneself be moved, is more common among the male audience than among the female (Höijer, 1996; Höijer, in press). Some explanations to that might be found rooted in the cultural fostering of boys and men, ideals and myths of manliness. Compassion fatigue may be another reason for the distantiation from the media pictures of innocent victims of war, conflicts and terror. According to Tester (2001: 13):
Compassion fatigue is becoming so used to the spectacle of dreadful events, misery or suffering that we stop noticing them. We are bored when we see one more tortured corpse on the television screen and we are left unmoved ... [...] Compassion fatigue means being left exhausted and tired by those reports and ceasing to think that anything at all can be done to help.

The concept "compassion fatigue" seems to imply an earlier stage with some compassion. The large amount of reports on suffering and the repetitive and stereotyped character of the depictions may tire the audience out. You do not need to be cynical and totally ignorant to other people's suffering in order to be fatigued and blunted. When the refugee catastrophe in Kosovo continued for several weeks and the media reported almost every day, many in the audience became tired. Especially women reported 
how they could not stand watching in the end and they told the interviewer how their compassionate reactions had turned into compassion fatigue (Höijer, 2002). A later new human catastrophe somewhere else in the world may, however, evoke their compassion again.

When discussing the impact of the growing television exposure of human suffering on the audience it is important not to simplify the discussion. We should not idealise the audience believing that all we need in order to awake compassion and engagement is to expose people to pictures of humanitarian disasters. Neither should we believe the opposite, that the audience mainly turn away in cynicism and compassion fatigue fed up by reportages of expulsions, massacres, genocide, terrorist and bomb attacks.

\section{The Ideal Victim}

Compassion is, as already mentioned, dependent on cognitions of innocent victims which, in turn are related to how we conceive the causes and perpetrators. The cognitions differ depending on social, cultural, political and historical circumstances. For example, earlier in our Western culture, and still in some cultures, physically punishing a child, or beating one's wife, was not considered a violent act. A debated case in Sweden recently was that of a man who kicked his three-year old stepson to death and received a very mild sentence.

As a cultural-cognitive construction the discourse of global compassion simply designates some victims as "better" victims than others. According to the moral ideals of the humanitarian organisations there should be no social boundaries for qualifying as a victim worthy of help. However, as well in international politics as in the media many victims never qualify as worthy victims. The hundred thousands of victims of the civil wars in Liberia and Sudan in the middle of the 1990s are two "forgotten" examples discussed by Minear, Scott and Weiss (1996). Chomsky (1999) asks why Western powers do not pay attention to the Kurdish victims, and there are many more examples, such as Sierra Leone, Burundi, Ethiopia and Eritrea. The situation for the civil population in Afghanistan and in the refugee camps in Pakistan did not receive very much attention before the area became an interest for global politics, or more precisely for the U.S. and Britain, in the fight against terrorism.

Further, some victims within an area picked out by the West are worthier; i.e. they are perceived to deserve our empathy better than others. According to the propaganda model for mass media, by
Herman and Chomsky (1988: 38), there are worthy and unworthy victims: People abused in what are regarded as enemy states are portrayed "as worthy victims, whereas those treated with equal or greater severity by its own government or clients will be unworthy". Worthy and unworthy relates to the extent and character of the political and mass media attention and indignation. Herman and Chomsky bring up examples from the beginning of the 1980s when the ideological struggle between capitalism and communism still ruled the world. A Polish priest murdered by the Polish police could, for example, become a worthy victim while hundreds of religious victims in countries in Latin America supported by the U. S. were unworthy victims whose destinies the mass media hardly paid any attention to at all. A more recent example, discussed by Chomsky (1999) is Kurdish victims of Turkish oppression and terror who have received very little attention compared to the Kosovo-Albanian victims of Serbian violence. The NATO country Turkey belongs to the friends whose encroachment we tend to close our eyes to. A comparison of the Scandinavian media coverage of victims from the different sides of the Kosovo War shows a strong media focus on Kosovo-Albanian victims, i.e. the NATO supported side (Höijer, Nohrstedt and Ottosen, 2002). It was not until some time after the end of the war that civilian victims on the Serbian side, i.e. the enemy side, were reported, for example mass graves with Serbian individuals.

If we leave the macro-political level and turn to a more general socio-cultural level we may also discriminate between ideal and less ideal victims. Children, women and elderly people are often seen as helpless in a violent situation and therefore they are more suitable as ideal victims than males in their active age (Christie, 1996). "Mothers and children make ideal victims", writes Moeller (1999: 107) in her critical discussion of the television covering of famine, "men associated with violent political factions can starve by the thousands without creating a flutter of interest in their victim status. The men are culpable, it is assumed, in not only their own deaths, but in the deaths of the truly blameless. Only when victims have been identified as "bona fide' are they candidates for compassion". But even if the media stereotype of the ideal victim is pictures of women and children we may also include elderly men as ideal victims because we generally perceive elderly people, including men, as physically very weak and in need of help from others. This was evident in reactions of the audience on the media reporting of the Kosovo War (Höijer, 2002). 
That the ideal victim is a cultural construction also becomes apparent if we consider historical and cultural variations in the victim status of women. Women who are assaulted by men are not always seen as victims, in some cultures not at all. Without any sense of compassion from people an elderly woman could be burned to death in a witch trial some hundred years ago in Scandinavia. And it is not until our present time that male soldiers' systematic rapes of civil women from the enemy side are being condemned. During the Second World War it was more or less accepted that Russian soldiers, for instance, committed massive rapes of German women immediately after the capture of Berlin.

\section{Conclusions}

Initially it was stated that it is in the intersection between politics, humanitarian organisations, the media and the audience/citizens, that the discourse of global compassion develops. Being more precise is hard since there is a huge span within each of these institutional and social levels, as well as between them, and we know very little about how they are related. The purpose of this article has simply been to identify a complex globalising process, which here has been named the discourse of global compassion.

The discourse of global compassion is not the altruistic discourse that it seems to be on a rhetorical level. Humanitarian organisations may be the party most sincerely committed to compassion and giving aid, but they have different policies; may sometimes keep most of the money themselves; and they may make the victims passive, keeping them

\section{Notes}

1. Lecture given at the conference "Genre 2001" at Oslo University College, May 13th-16th, 2001.

2. Lecture given at the conference "Genre 2001" at Oslo University College, May 13th-16th, 2001.

3. Fairclough defined "genres" as "ways of (inter) acting in their semiotic aspect; ways of regulating (inter)action", and "styles" as "ways of being, identities, in their discourse aspect (cp material, bodily, aspect)". Lecture with hand-out given at Oslo University, May 16th, 2001.

4. Potter and Wetherell (1987: 6) several years ago pointed out that "it is perfectly possible to have two books on discourse analysis with no overlap in from solving their situation on their own. In politics, global compassion must fit into power interests in order to be interesting, and there may be economic and power interests hiding behind the rethoric. The media may expose human suffering as part of commercial interests and in the purpose of getting attention. There are many violent conflicts and disasters in the world with huge human suffering as a consequence that get no attention, neither from international politics nor from the media. The audience donate some money and then turn their backs on the people suffering in other parts of the world.

But this is a much too simplified and negative picture. There are also more positive traits in the development. Human rights is linked to democracy and is an important agenda for global politics. A journalism of attachment may be a project with honest and serious intentions for concerned journalists. Many in the audience, especially among the female audience, are seriously moved by media reports of distant suffering. That people give money when telethons are broadcasted means money for aid. Many citizens also take part in subscription campaigns in other ways and a growing number are engaging in humanitarian organisations. And without the money and the efforts of the humanitarian organisations many, many millions of people would certainly die.

Both pictures above are valid. The discourse of global compassion is a complex phenomenon with good and bad characteristics living side by side. For media research there are many compelling questions about the discourse of global compassion waiting to be empirically studied. content at all", and the confusion has not lessened since then.

5. For a discussion of The New World Order see Nohrstedt and Ottosen (2000).

6. Financial Times quoted in Guardian Unlimited. http//:www.guardian.co.uk/weblog/special/ 0,10627,559063,00.html

7. Lynch (1998: 11) defines corporate compassion as "a willingness to recognize fallibility, vulnerability and misfortune, responding to them in ways that are morally sound, respectful of the victim as a human being, supportive of action which will enable those willing to improve their circumstances wherever feasible". According to his view it is dangerous for an organisation to be seen as 
heartless in the way it treats people. He argues that companies must treat employees, shareholders, suppliers, local communities and the environment with the same respect with which they treat their customers.

8. Human sponsoring was discussed in the programme "Agenda" on Swedish Television, January 21st 2001.

9. Establishment of an International Criminal Court. http://www.un.org/law/icc/general/overview.htm

10. Andén-Papadopoulos (2000) shows in her study of the press that the photographic pictures during the Vietnam War 1965 - 1972 mostly depicted the war as a military operation, the soldiers' everyday life, and the political actors of the war. Most of the pictures of the victims of the war showed American or South Vietnamese soldiers getting help.

11. In 2002 the campaign was led by Peter Hjukström and eleven humanitarian organisations participated.

12. http://www.svt.se:Världens Barn (http://svt.se/svt/ jsp/Crosslink.jsp?d=181)

13. www.nrk.no/tv-aksjonen

14. Norwegian newspaper Aftenposten, 091200

15. Expressen, 200109 23. Celebrities such as Julia Roberts, Bruce Springsteen, Eric Clapton, Stevie Wonder, and Clint Eastwood performed.

16. http://www.strix.se

17. Röda Korsets Tidning, nr 3, 2000.

\section{References}

Andén-Papadopoulos, K. (2000) Kameran i krig. Den fotografiska iscensättningen av Vietnamkriget $i$ svensk press (The Camera in War. The Vietnam War in Swedish Press). Stockholm/Stehag: Symposion.

Andresen, Ø. (1999) Organisasjonsdeltakelse i Norge fra 1983 til 1997 (Participation in NGO:s in Norway 1983 - 1997). Oslo: Statistisk sentralbyrå.

Beck, U. (2000) What is Globalization? Cambridge, UK: Polity Press.

Bell, M. (1998) The Journalism of Attachment. Pp 1522 in M. Kieran (ed.), Media Ethics. London: Routledge.

Beetham, D. (1998) Democracy and Human Rights: Civil, Political, Economic, Social and Cultural. Pp 71-97 in J. Symonides (ed.), Human Rights: New Dimensions and Challenges. Aldershot, UK: Ashgate.

Björnemyr, N. and I. Wahlqvist (2002) Mediernas bild av civila offer efter 11 september, 2001. En jämförande studie av rapporteringen i Dagens Nyheter och New York Times efter terrorattackerna i USA och kriget i Afghanistan. Örebro Universitet, Medier och kommunikationsvetenskap, C-uppsats.

Boltanski, L. (1999) Distant Suffering. Morality, Media and Politics. Cambridge: Cambridge University Press.

Carlgren, A. (1996) TV:s krigsbilder kränker verkligheten (The Pictures of War on Television Violates
Reality). Pp 57-81 in Andén-Papadopoulos, K. and B. Höijer (eds.), Våldsamma nyheter. Stockholm/Stehag: Symposion.

Chomsky, N. (1999) The New Military Humanism. Lessons from Kosovo. Monroe, ME: Common Courage Press.

Christie, N. (1996) The Ideal Victim. Pp 17-30 in E. A. Fattah (ed), From Crime Policy to Victim Policy. London: MacMillan Press.

Cronström, J. (2000) Gränslöst II: om det symboliska $T V$-våldets inflytande på individer, medier och samhälle. Stockholm: Institutionen för journalistik, medier och kommunikation (licentiatuppsats).

Devereux, E. (1996) Good Causes, God's Poor and Telethon Television. Media, Culture \& Society, 18: 47-68.

Fairclough, N. (1989) Language and Power. London: Longman.

Herman, E. S. and N. Chomsky (1988) Manufacturing Consent. The Political Economy of the Mass Media. New York: Pantheon Books.

Höijer, B. (1994) Våldsskildringar i TV-nyheterna. Produktion, utbud, publik (Violent News. Production, Text, Audience). Stockholm University: Department of Journalism, Media and Communication, No. 5.

Höijer, B. (1996) The Dilemmas of Documentary Violence in Television. Nordicom Review, 1, 5361.

Höijer, B., Nohrstedt, S. A. and R. Ottosen (2002) The Kosovo War in the Media - Analysis of a Global Discursive Order. Conflict \& Communication Online, 1(2): www.cco.regener-online.de

Höijer, B. and U. Olausson (2002) Medborgare om medierna och Kosovokonflikten. Örebro University: Studies in Media and Communication, No 23.

Höijer, B. (2003) The Discourse of Global Compassion. The Audience and the Media Reporting of Human Suffering. Media, Culture \& Society, in press.

Ignatieff, M. (1998) The Warrior's Honor. Ethnic War and the Modern Conscience. New York: Henry Holt and Company.

Jeppsson Grassman, E. and L. Svedberg (1999) Medborgarskapets gestaltningar. Insatser i och utanför föreningslivet (The Formation of Citizenship). Ingår i Civilsamhället. Demokratiutredningens forskarvolym VIII. SOU 1999:84.

Johnstone, D. (2000) Nato and the New World Order: Ideals and Self-Interest. Pp 7-18 in P. Hammond and E. S. Herman (eds), Degraded Capability: The Media and the Kosovo Crisis. London: Pluto Press.

Jørgensen Winter, M. and L. Phillips (1999) Diskursanalyse som teori og metode (Discourse Analysis as Theory and Method). Roskilde: Roskilde Universitetsforlag.

Karvonen, L. (1999) Då demokratin svalnar. Om valdeltagande, förtroende och intresse (When Democracy Cool Down). Pp 8-17 in H. Hvitfelt och L. Karvonen (eds.), Den svala demokratin. Sundsvall: Demokratiinstitutet. 
Kjellqvist, E. B. (1996) När bild blir trauma (When Pictures Become Traumatic). Pp 55-74 in A. Berge et. al., Inre och yttre hotbilder. Psykoanalytiker ser på våld i media. Stockholm: Våldsskildringsrådet, No.13.

Lynch, J. J. (1998) Corporate Compassion. Succeeding with Care. London: Cassell.

Mellum, M. (2000) Journalister i krig - en studie av norske avisjournalisters dekning av Kosovokrigen 1999 (Journalists in War). University of Oslo: Department of Media and Communication (hovedfagsoppgave).

Minear, L., Scott,C. and T.G.Weiss (1996)The News Media, Civil War, and Humanitarian Action. Boulder, Colorado: Lynne Rienner Publishers.

Moeller, S. D. (1999) Compassion Fatigue. How the Media Sell Disease, Famine, War and Death. New York: Routledge.

Natsios, A. (1996) Illusions of Influence: The CNN Effect in Complex Emergencies. Pp 149-169 in R. I. Rotberg and T. G. Weiss (eds), From Massacres to Genocide. The Media, Public Policy, and Humanitarian Crises. Cambridge, Mass.: The World Peace Foundation.

Nohrstedt, S. A. (1986) Tredje världen i nyheterna (The Third World in the News). Stockholm: Almqvist \& Wiksell International.

Nohrstedt, S. A. and R. Ottosen (eds). Journalism and the New World Order. Gulf War, National News Discourses and Globalization. University of Gothenburg: Nordicom.

Nussbaum, M. C. (2001) Uppheavals of Thought. The Intelligence of Emotion. Cambridge: Cambridge University Press.

Olausson, U. (2002) Sanningen har ju alltid två sidor. Svenska medborgare om Kosovokonflikten och medierna. Ingår i Höijer, B. och U. Olausson: Medborgare om medierna och Kosovokonflikten.
Örebro University: Studies in Media and Communication, No 23.

Ottosen, R. (1995) Enemy Images and the Journalistic Process. Journal of Peace Research, 32(1): 97112.

Ottosen, R. (2002) Pressfriheten under press efter 11. september (The Freedom of the Press Under Pressure After September 11th). Oslo: Norsk Redakørforenings Arbok 2001.

Potter, J. and M. Wetherell (1987) Discourse and Social Psychology. Beyond Attitudes and Behaviour. London: Sage.

Sassen, S. (1998) Globalization and Its Discontents. Essays on the New Mobility of People and Money. New York: The New Press.

Sznaider, N. (1998) The Sociology of Compassion: A Study in the Sociology of Morals. Cultural Values, 2(1): 117-139.

Thörn, H. (1999) Nya sociala rörelser och politikens globalisering. Demokrati utanför parlamentet? (New Social Movements and the Globalisation of Politics). Demokratiutredningens forskarvolym, VIII. Civilsamhället. SOU 1999:84.

Tester, K. (1994) Media, Culture and Morality. London: Routledge.

Tester, K. (2001) Compassion, Morality and the Media. Buckingham: Open University Press.

Tvedt, T. (1993) En studie av frivillige organisasjoner $i$ norsk bistand (A Study of NGO:s in Norwegian Aid). Universitetet i Bergen, Senter for utviklingsstudier.

Tvedt, T. (1995) Den norske samaritan. Ritualer, selvbilder og utviklingshjelp (The Norwegian Samaritan). Oslo: Gyldendal.

Zizek, S. (2001) 'Njutning förbjuden', Dagens Nyheter, 01-08-22. 